\title{
Effect of Mancozeb on Disease Severity, Infection Rate and Seed Weight of Mustard [Brassica juncea (L.) Czen \& Coss.] Caused by Alternaria spp.
}

\author{
Manoj Kumar Pandey ${ }^{1}$, Narender Kumar ${ }^{2}$, Hemant Kumar Singh ${ }^{1}$ \\ and Surender Kumar ${ }^{2 *}$
}
${ }^{1}$ Department of Plant Pathology, N. D. University of Agriculture and Technology, Faizabad-224229, U.P., India
${ }^{2}$ C. S. Azad University of Agriculture and Technology, Kanpur-208002, India
*Corresponding author

\section{A B S T R A C T}

\begin{tabular}{|c|c|}
\hline $\mathbf{K e}$ & \multirow{4}{*}{$\begin{array}{l}\text { In case of fungicidal trails all the treatments reduced the disease severity in comparison to } \\
\text { unsprayed plots. The severity of disease after eight spray of Mancozeb @ } 0.2 \% \text { was found } \\
\text { minimum disease severity }(5.0 \%) \text { followed by seven spray }(6.0 \%) \text { and six spray }(10.33 \\
\% \text { ), respectively. Maximum seed yield of } 2000 \mathrm{~kg} / \mathrm{ha} \text { was recorded with eight spray of } \\
\text { Mancozeb @ } 0.2 \% \text { followed by seven spray }(1922.22 \mathrm{~kg} / \mathrm{ha}) \text {, and six spray }(1902.77 \\
\mathrm{kg} / \mathrm{ha} \text { ), respectively. Similar trend was recorded in case of test weight also. All the } \\
\text { treatments avoided test weight loss of } 5.70 \text { to } 21.81 \% \text {. Maximum being with eight and } \\
\text { seven spray of Mancozeb @ } 0.2 \%(21.81 \%) \text { followed by six spray }(21.67 \%) \text { and five } \\
\text { spray (20.81\%).Maximum yield loss of } 48.61 \text { per cent was also avoided with eight spray } \\
\text { of Mancozeb @ } 0.2 \% \text { followed by seven sprays }(46.53 \%) \text { and five spray ( } 45.94 \%) \text {.The } \\
\text { maximum benefit cost ratio of } 1: 7.94 \text { and } 1: 7.18 \text { were obtained with four and three spray } \\
\text { of Mancozeb @ } 0.2 \% \text { followed by five sprays }(1: 6.82) \text { and two spray }(1: 6.11) \text {. }\end{array}$} \\
\hline & \\
\hline & \\
\hline & \\
\hline
\end{tabular}

\section{Introduction}

Oilseed crops play an important role in agricultural economy of India. Oilseed brassicas often called rapeseed-mustard Kumar et al., (2014) placed in Brassicaceae family which contains about 3500 species and 350 genera, is one of the 10 most economically important plant families. According to ancient scripture and literature, it has been cultivated as early as 5000 BC. There is evidence of its cultivation in Neolithic age. Seeds of mustard were found from the Channhudaro of Harrapan civilization ca. 2300-1750 BC. Among the oilseed brassicas, mustard (Brassica juncea), yellow sarson (B. campestris var. yellow sarson), brown sarson (B. campestris var. brown sarson), toria (B. campestris var. toria), oilseed rape (B. napus) and Karan rai (B. carinata) are grown for edible oil whereas black mustard ( $B$. nigra) is used as a condiment for pickle making Kumar et al., (2014).

Among rapeseed-mustard, Indian mustard [Brassica juncea (L.) Czern \& Coss.] is one 
of the most important oilseed crops which contribute about 85 per cent of total rapeseedmustard produced in India (Kumar and Chauhan (2005). Green leaves of young plants are used as vegetable. The oilseed brassicas usually contain $38-57 \%$ of erucic acid, 4.7-13\% of linolenic acid and $27 \%$ of oleic and linoleic acids Kumar et al., (2014). The protein content ranges between 24-30 per cent of the whole seed and 35-40 per cent of the meal.

Among the entire oilseed crops producing states in India and in U.P. the area under cultivation is 6.39 lakh hac, with production of 7.9 lakh metric tonnes and productivity of $12.36 \mathrm{q} / \mathrm{ha}$ (Anonymous, 2013). This lower production is attributable mainly due to biotic and abiotic stresses. Among the biotic stresses, fungal folior diseases, viz. Alternaria blight caused by Alternaria brassicae (Berk) Sacc. and Alternaria brassicicola (Schwin) Wiltshire, White rust caused by Albugo candida (Lev.) Kunze, Downy mildew caused by Peronospora parasitica (Pers.) ex Fr. and Powdery mildew caused by Erysiphe cruciferarum Opiz ex. Junell are most important and individually or collectively, cause enormous losses.

Among the various diseases, Alternaria blight is caused by Alternaria brassicae (Berk) Sacc. and Alternaria brassicicola (Schwin) Wiltshire is one of the most severe yield destabilizing factor causing reduction from 35 to 45 per cent Kolte et al., (1987); Saharan (1992); Kolte (2002) and inflicts very severe losses up to 70 per cent in yield of rapeseed and mustard crops of yellow and brown sarson Saharan (1992); Kolte (2002). The disease also adversely affects quality by reducing seed size, impairing seed colour and oil content.

The blight disease of brassicas caused by $A$. brassicae was first time reported in England on English cabbage Berkley (1836). In India, it was first recorded from Tirhoot division, (Pusa) in 1901 on sarson by Butler (1918). In subsequent years this disease was also reported from many other parts of world Ceylon Bond (1947), Germany Borg (1952). In Utter Pradesh (Presently Uttarakhand) it was reported from Pantnagar by Kolte and Tiwari (1978).

The resistance identified in different genotypes of mustard is partial. The extent of losses caused by this disease was also variable from place to place, depending upon the severity of disease (Barma and Bhagawati (1995). Keeping in view, to know the development of disease in different genotypes and extent of losses caused by this disease under different spray schedule. Considering the above point on view, the study was undertaken on the present investigation as "Effect of mancozob on disease severity, infection rate and seed weight of Mustard [Brassica juncea (L.) Czern \& Coss.] caused by Alternaria spp".

\section{Materials and Methods}

The present investigation was carried out at the Student's Instructional Farm (2013-2014) Department of Plant Pathology, College of Agriculture, Narendra Deva University of Agriculture and Technology, Kumarganj, Faizabad (U.P). Different varieties/ genotypes of Brassica juncea were procured from the All India Co-ordinated Research Project on Rapeseed-Mustard, Department of Genetics and Plant Breeding of the University.

\section{Land preparations and raising of crop}

The land was well prepared by one deep ploughing with soil turning plough, followed by two cross harrowing. Entire field was marked with rope to have sowing in rows at $30 \mathrm{~cm}$ spacing between two rows. Field was also divided in blocks and plots to provide channels for irrigation and drainage. 


\section{Fertilizers applications}

The recommended dose of fertilizers $(\mathrm{N}$ : $\mathrm{P}$ : $\mathrm{K}-120: 60: 60 \mathrm{~kg} / \mathrm{ha}$ ) was applied in the form of urea, single super phosphate and murate of potash. Half dose of nitrogenous fertilizer and full dose of phosphorus and potash were applied in furrows as basal dressing at the time of sowing. Remaining half dose of nitrogenous fertilizer was given as top dressing in two split doses, one after first irrigation and second at the time of flowering.

\section{Studies on development of Alternaria blight in different genotypes}

This experiment was conducted during Rabi 2013-2014 at Student's Instructional Farm of the N.D. University of Agriculture and Technology, Kumarganj, Faizabad by planting fifteen genotypes of the Indian mustard namely NDWR-05-1, NDRE-22, Varuna, NDR-8501, NDRE-7, NDR-2011, NDRS-2010, NDRE-4, PRB-2004-3, Ashirwad, JD-6, NDRE-8213, NDYR-32, NDRE-16 and NDYR-8. Each genotypes were sown in well prepared and fertilized field in five lines of three meter length having spacing of $30 \mathrm{~cm}$ from line to line and $10 \mathrm{~cm}$ from plant to plant on October 22, 2013. All the entries were also flanked by two rows of susceptible check. All the cultural operations were adopted as per recommendation for raising the good crop.

\section{Observations recorded}

After germination the crop was regularly observed for first appearance of disease. The number of spots was counted per $10 \mathrm{~cm}^{2}$ leaf area on different tagged leaves with the half of a glass slide, on which $5 \times 2 \mathrm{~cm}^{2}$ area was marked with permanent markers. Observations were taken on lower leaf, middle leaf and upper leaf at five places per leaf lamina on upper surface of leaf, starting from lower most leaf to the upper most fully developed leaves. This method of counting of spots was followed in all the successive observations. Average number of spots calculated. Alternaria blight spots were also counted on pods, one week prior to maturity of the plant. A total of twenty five pods @ 5 pods per plant per genotype per replication were observed and average number of spots per pod was calculated.

Randomly five plants were selected in each genotype for measuring the spot size. From each plant, five leaves were randomly selected on which diameter of randomly selected spots were measured in $\mathrm{mm}$.

Average size of leaf spot in each genotype was calculated. Five largest spots per infected pod of the selected plants were measured and average was calculated on the basis of fifty spots /genotype.

The spore production in different genotypes at different intervals on spots of Alternaria blight, the affected leaves were thoroughly washed in running tap water and the lesion of similar size were taken at different intervals and separated by cork borer $(8 \mathrm{~mm})$. These lesions were surface sterilized with $0.1 \%$ mercuric chloride and further washed repeatedly in sterilized distilled water. Sporulation was observed by suspending sporulated lesions in vials containing a mixture of distilled water + lactophenol in the ratio of 9:1. These lesions were than shaken vigourously and scrapped with the help of a camel hair brush. The conidia were counted with the help of a haemocytometer.

The infected pods of above genotypes were collected from the field at different intervals and thoroughly washed in running tap water. The pods were cut in $6 \mathrm{~mm}$ pieces containing single spot. Fifteen such surface sterilized pieces were incubated in Petri plates in a moist chamber for 48 hours at room temperature $\left(25^{\circ} \mathrm{c}\right)$ with alternating 12 hours 
light and 12 hours dark periods. Conidia were counted as per method described above.

The observations on disease severity were recorded by selecting five plants randomly from each genotype. The disease severity was recorded at 10 days intervals to till maximum disease severity by using 0-6 rating scale as suggested in the Proceedings of All India Coordinated. Research Project on Rapeseedmustard pathology, Planning and Review session-2009-10 given below.

Observations were noted on lower, middle, and upper leaves of randomly selected five plants from each genotype and in each replication.

The per cent disease intensity (PDI) was calculated by employing formula mentioned below:

PDI $=\frac{\text { Sum of total numerical ratings }}{\text { Total number of leaves observed }} \times \frac{100}{\text { Highest grade }}$

The period from the initial appearance of symptoms and the final incidence of the disease was also considered and the apparent infection rate of the disease spread was calculated according to the following formula (Vander plank, 1963).

Infection rate $(r)=\frac{2.3}{t_{2}-t_{1}} \log _{e} \frac{x_{2}\left(1-x_{1}\right)}{x_{1}\left(1-x_{2}\right)}$

Where,

$\mathrm{t}_{1}=$ time during first observation

$\mathrm{t}_{2}=$ time (days) during second observations

$t_{2}-t_{1}=$ time intervals between two observations

$\mathrm{x}_{1}=$ percent disease intensity value in decimal at corresponding $t_{1}$ time

$\mathrm{x}_{2}=$ percent disease intensity value in decimal at corresponding $\mathrm{t}_{2}$ time

$\log \mathrm{e}=$ natural $\log$

The Area under Disease Progress Curve (AUDPC) was calculated by the formula as under:

$$
\mathrm{AUDPC}=\sum_{\mathrm{i}=1}^{\mathrm{n}}\left[\left(\mathrm{Y}_{\mathrm{i}+1}+\mathrm{Y}_{\mathrm{i}}\right) \times 0.5\right]\left[\mathrm{T}_{\mathrm{i}+1}+\mathrm{T}_{\mathrm{i}}\right]
$$

Where,

$\mathrm{Y}_{\mathrm{i}}=$ Alternaria blight severity $(\%)$ at the $\mathrm{I}^{\text {st }}$ observation

$\mathrm{T}_{\mathrm{i}}=$ Time (days) of the $\mathrm{I}^{\text {st }}$ observation

$\mathrm{n}=$ Total number of observations

For the observations of leaf defoliation, leaves were counted from basal to top.

Average was taken based on 5 plants of each genotype in each replication and per cent leaf defoliation was calculated by employing formula mentioned below.

Leaf Defoliation $(\%)=\frac{\text { Sum of total infected defoliate leaves }}{\text { Total number of leaves }} \times 100$

Seed yield was recorded in each genotype separately to determine the differences in yield between each genotype and yield $\mathrm{kg} \mathrm{ha}^{-1}$ was calculated.

\section{Spraying of chemical}

Solution of required amount of Mancozeb prepared with water and volume made up to the desired level. This prepared solution was sprayed by using high volume Knap sack sprayer of 10 liter capacity.

As per technical programme eight sprays of Mancozeb were given starting from first appearance of disease followed by 10 days intervals in the plots. 


\section{Statistical analysis}

The data wherever required was statistically analyzed following standard statistical procedures Fisher and Yates (1957).

\section{Result and discussion}

\section{Development of disease on different} genotypes

The data presented in Table 1, showed the number of spots $/ 10 \mathrm{~cm}^{2}$ on leaves and pods, size of spots $(\mathrm{mm})$ on leaves and pods, conidia per spots on leaves and pods. The disease first appeared on the genotype NDRS2010 (38 DAS) followed by genotypes Ashirwad (42 DAS), Varuna (44 DAS) and NDR- 8501 (45 DAS). The latest appearance of disease was noted on genotype JD-6 (63 DAS) (Table 2).

\section{Yield of different genotypes}

The seed yield was ranged from 1090.0 to $1608.3 \mathrm{~kg} / \mathrm{ha}$ in different genotypes/cultivar. The maximum seed yield was recorded in cultivar NDRE-7 $(1608.3 \mathrm{~kg} / \mathrm{ha})$ followed by NDWR-05-1(1516.7 kg/ha) and NDRE-4 $(1425.0 \% \quad \mathrm{~kg} / \mathrm{ha})$. The NDRE-7 (1608.3 $\mathrm{kg} / \mathrm{ha})$ and NDWR-05-1(1516.7 kg/ha) were at par in respect of seed yield. However, the genotype NDER-4 (1425.0 kg/ha) significantly differ from NDRE-7 and NDWR-0501. The minimum yield was recorded on cultivar Varuna $(1090.0 \mathrm{~kg} / \mathrm{ha})$ followed by NDRS-2010 (1250.0 kg/ha), Ashirwad (1283.0kg/ha) and NDR-2011 (1300.0kg/ha) (Table 2).

Correlation coefficient among different components of partial resistance and yield of mustard genotypes

All the components were highly significant and positively correlation with each other except sporulation which have negative correlation with yield. The highest value of correlation was recorded between disease index and infection rate $(\mathrm{R}=0.966)$ followed by disease index and AUDPC ( $\mathrm{R}=0.960)$, whereas lowest value of correlation was recorded between leaf defoliation and sporulation $(\mathrm{R}=0.032)$. It means disease index is the most determinant factor for partial resistance that greatly influences the development and progression of epidemic.

The number of spot were positively associated with size of spot (0.949), disease index (0.905), leaf defoliation (0.954), AUDPC (0.917), infection rate (0.878) and negatively associated with yield $\mathrm{kg} / \mathrm{ha} \mathrm{(-}$ 0.952 ). Size of spot is highly significant and positive correlated with disease index (0.891), leaf defoliation (0.907), AUDPC (0.828) infection rate (0.917) and negatively correlated with yield $\mathrm{kg} / \mathrm{ha}(-0.877)$. Disease index is highly significantly associated with leaf defoliation (0.912), AUDPC (0.960), infection rate (0.966) and negatively correlated with yield $\mathrm{kg} / \mathrm{ha}(-0.812)$. Leaf defoliation was significantly positively correlated with AUDPC (0.932), infection rate $(0.861)$ and negatively correlated with yield $\mathrm{kg} / \mathrm{ha}$ (-0.952). Sporulation was positive correlation with AUDPC (0.331), infection rate $(0.147)$ and negatively correlated with yield $\mathrm{kg} / \mathrm{ha} \quad(-0.001)$. AUDPC was significantly positive associated with infection rate (0.892) and negatively associated with yield $\mathrm{kg} / \mathrm{ha}(-0.860)$ and infection rate was significantly negatively correlated with yield (-o.761).

\section{Per cent disease severity (PDI)}

The results revealed that all the treatments significantly reduced the disease severity in comparison to untreated plot. The disease severity (PDI) on leaves ranged from 5.0 to $71.33 \%$. The minimum disease severity of $5.0 \%$ was recorded with eight spray of Mancozeb @0.2 followed by Seven spray of 
Mancozeb @ o.2\% (6.0\%), Six spray of Mancozeb@0.2\% (14.00\%), Five spray of Mancozeb @ $0.2 \%$ (20.17\%), Four spray of Mancozeb @ 0.2\% (36.0\%), and Three spray of Mancozeb @ 0.2\% (45.0\%). The maximum disease severity (PDI) was recorded in untreated plot $(71.33 \%)$. No significant difference was noted seven spray of Mancozeb@0.2\% and eight spray of Mancozeb@0.2\%while all other treatments were significantly differed from each other. Foliar spray of Mancozeb (@0.2\%) found effective in reducing the disease severity. Similar finding was reported by Meena et al., (2004); Mondal et al., (2008); Prasad et al., (2009)

In case of pod infection the disease severity
(PDI) ranged from 0 to $61.07 \%$. The zero disease severity (PDI) was recorded on pods with Eight spray of Mancozeb @ $0.2 \%$ followed by Seven spray of Mancozeb @ 0.2 $\%(3.50 \%)$, Six spray of Mancozeb @ $0.2 \%$ (10.33, Five spray of Mancozeb @ $0.2 \%$ (12.67\%), Four spray of Mancozeb @0.2\% (20.0\%), Three spray of Mancozeb @ $0.2 \%$ (32.38\%), Two spray of Mancozeb@0.2\% (40.07\%), One spay of Mancozeb @0.2\% $(50.0 \%)$ and maximum disease severity (PDI) was found in Unsprayed plot (61.07 \%). There was no significant difference among treatment $T_{5}$ and $T_{6}$. However, all other treatments were significantly differing from each other Girish et al., (2007)

\section{Detail of Treatments}

$\mathrm{T}_{1} \quad$ One spray of Mancozeb at disease initiation.

$\mathrm{T}_{2} \quad$ Two sprays of Mancozeb at disease initiation and after 10 days.

$\mathrm{T}_{3} \quad$ Three sprays of Mancozeb first at disease initiation and after 10 days intervals thereafter.

$\mathrm{T}_{4} \quad$ Four sprays of Mancozeb after 10 days intervals starting from first appearance

$\mathrm{T}_{5} \quad$ Five sprays of Mancozeb after 10 days intervals starting from first appearance

$\mathrm{T}_{6} \quad$ Six sprays of Mancozeb after 10 days intervals starting from first appearance

$\mathrm{T}_{7} \quad$ Seven sprays of Mancozeb after 10 days intervals starting from first appearance

$\mathrm{T}_{8} \quad$ Eight sprays of Mancozeb after 10 days intervals starting from first appearance

$\mathrm{T}_{9} \quad$ Control (untreated)

\begin{tabular}{|c|c|c|}
\hline $\begin{array}{c}\text { Rating } \\
\text { scale }(0-6)\end{array}$ & Description of scale & Host reaction \\
\hline 0 & No visible symptoms & Free \\
\hline 1 & Up to $5 \%$ leaf area covered & $\begin{array}{l}\text { Highly } \\
\text { Resistant }\end{array}$ \\
\hline 2 & $\begin{array}{l}5-10 \% \text { leaf or pod area covered with small pin head spots } \\
\text { on the leaves and superficial pinhead spots on pods }\end{array}$ & Resistant \\
\hline 3 & $\begin{array}{l}10-20 \% \text { leaf or pod area covered with small spots on the } \\
\text { leaf and superficial pin head spots on pods }\end{array}$ & $\begin{array}{l}\text { Moderately } \\
\text { Resistant }\end{array}$ \\
\hline 4 & $\begin{array}{l}20-30 \% \text { leaf or pod area covered with bigger spots with } \\
\text { initiation of coalesces on leaves and deep lesion on pods }\end{array}$ & $\begin{array}{l}\text { Moderately } \\
\text { Susceptible }\end{array}$ \\
\hline 5 & $\begin{array}{l}30-50 \% \text { leaf or pod area covered with bigger spots } \\
\text { commonly coalescing spots on leaves and deep lesion on } \\
\text { pods }\end{array}$ & Susceptible \\
\hline 6 & $\begin{array}{l}\text { More than } 50 \% \text { leaf or pod area covered giving blighting } \\
\text { appearance }\end{array}$ & $\begin{array}{c}\text { Highly } \\
\text { Susceptible }\end{array}$ \\
\hline
\end{tabular}


Table.1 Effect of Mancozeb under different spray schedule on the disease severity (PDI) of Alternaria blight of mustard cv. Varuna during 2013-2014

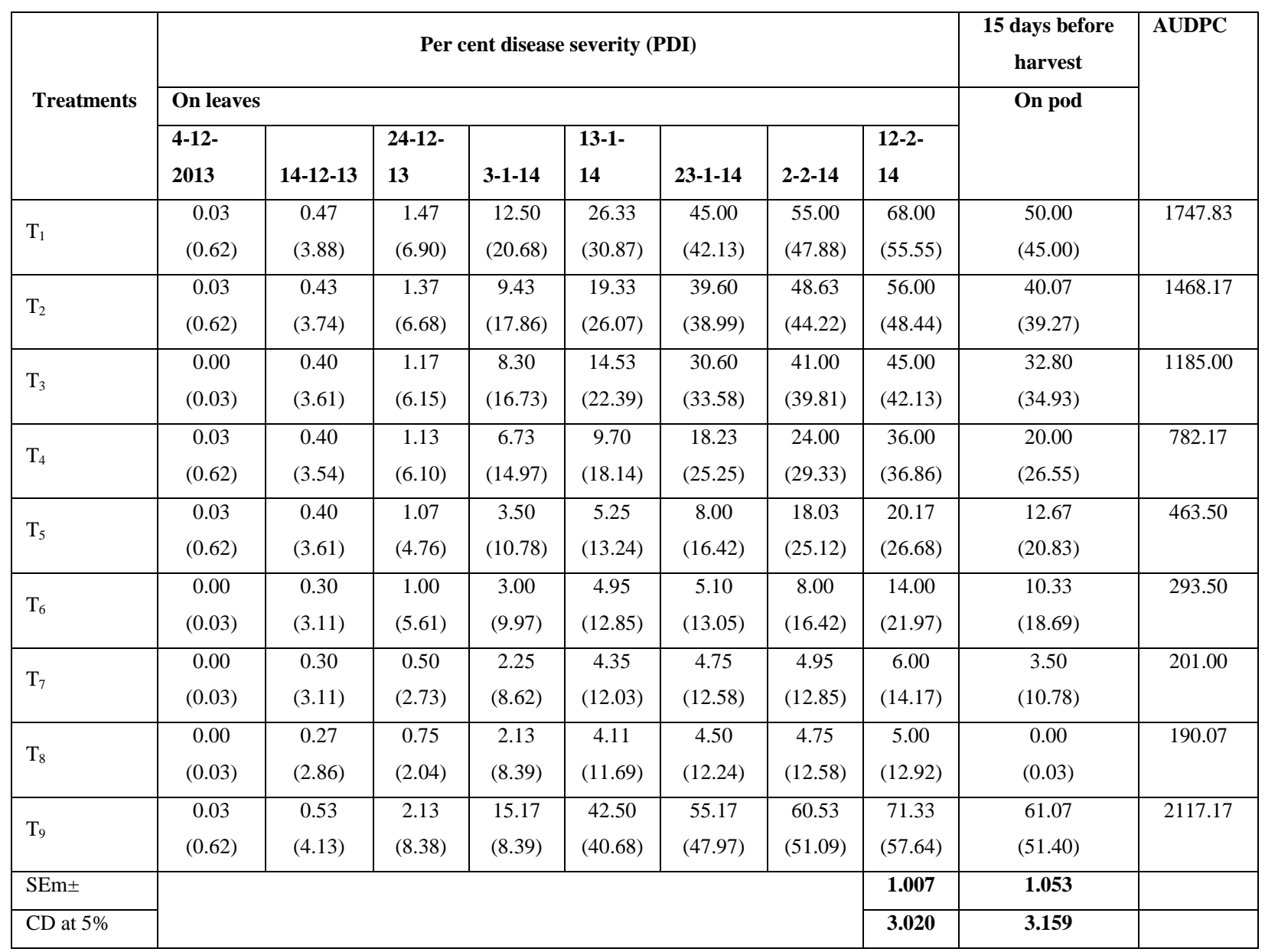

Table.2 Effect of Mancozeb on apparent infection rate (r) of Alternaria blight of mustard cv. Varuna during 2013-14

\begin{tabular}{|c|c|c|c|c|c|c|c|c|}
\hline \multirow[b]{2}{*}{$\begin{array}{c}\text { Treatmen } \\
\text { ts }\end{array}$} & \multicolumn{8}{|c|}{ Infection rate on leaves (DAS/Date) } \\
\hline & $\begin{array}{c}4-12-13 \\
\text { to } 14-12- \\
13 \\
\end{array}$ & $\begin{array}{c}15-12-13 \\
\text { to } 24-12- \\
13 \\
\end{array}$ & $\begin{array}{l}25-12-13 \\
\text { to } 3-1-14\end{array}$ & $\begin{array}{c}4-1-14 \\
\text { to } 13-1- \\
\quad 14\end{array}$ & $\begin{array}{l}14-01- \\
2014 \text { to } \\
23-1-14\end{array}$ & $\begin{array}{c}24-2-14 \\
\text { to } 2-2- \\
14\end{array}$ & $\begin{array}{c}3-2-14 \\
\text { to } 12-2- \\
14\end{array}$ & Mean \\
\hline $\mathrm{T}_{1}$ & 0.377 & 0.165 & 0.323 & 0.131 & 0.118 & 0.057 & 0.079 & 0.179 \\
\hline $\mathrm{T}_{2}$ & 0.367 & 0.165 & 0.288 & 0.119 & 0.144 & 0.052 & 0.042 & 0.168 \\
\hline $\mathrm{T}_{3}$ & 0.355 & 0.150 & 0.263 & 0.057 & 0.104 & 0.050 & 0.082 & 0.152 \\
\hline $\mathrm{T}_{4}$ & 0.355 & 0.141 & 0.173 & 0.061 & 0.064 & 0.133 & 0.020 & 0.135 \\
\hline $\mathrm{T}_{5}$ & 0.0 & 0.154 & 0.291 & 0.090 & 0.136 & 0.065 & 0.023 & 0.126 \\
\hline $\mathrm{T}_{6}$ & 0.0 & 0.173 & 0.160 & 0.074 & 0.005 & 0.069 & 0.090 & 0.095 \\
\hline $\mathrm{T}_{7}$ & 0.0 & 0.073 & 0.217 & 0.097 & 0.013 & 0.006 & 0.029 & 0.073 \\
\hline $\mathrm{T}_{8}$ & 0.0 & 0.148 & 0.151 & 0.097 & 0.014 & 0.008 & 0.008 & 0.071 \\
\hline $\mathrm{T}_{9}$ & 0.396 & 0.200 & 0.300 & 0.203 & 0.073 & 0.031 & 0.069 & 0.182 \\
\hline
\end{tabular}


Table.3 Effect of Mancozeb under different spray schedule on test weight (1000 seed weight in gm) and seed yield of mustard cv. Varuna 2013-14

\begin{tabular}{|l|c|c|c|c|c|}
\hline \multirow{2}{*}{ Treatment } & Test weight & Avoidable test & \multicolumn{3}{|c|}{ Seed yield } \\
\cline { 4 - 6 } & (gm) & weight loss $(\%)$ & Kg/plot & Kg/ha & Avoidable loss \\
\hline $\mathrm{T}_{1}$ & 4.56 & 5.70 & 1.29 & 1072.22 & 4.14 \\
\hline $\mathrm{T}_{2}$ & 4.69 & 8.31 & 1.57 & 1311.11 & 21.61 \\
\hline $\mathrm{T}_{3}$ & 5.02 & 14.34 & 1.85 & 1541.66 & 33.33 \\
\hline $\mathrm{T}_{4}$ & 5.30 & 18.86 & 2.12 & 1763.88 & 41.73 \\
\hline $\mathrm{T}_{5}$ & 5.43 & 20.81 & 2.18 & 1819.44 & 43.51 \\
\hline $\mathrm{T}_{6}$ & 5.49 & 21.67 & 2.28 & 1902.77 & 45.94 \\
\hline $\mathrm{T}_{7}$ & 5.50 & 21.21 & 2.31 & 1922.22 & 46.53 \\
\hline $\mathrm{T}_{8}$ & 5.50 & 21.81 & 2.40 & 2000.00 & 48.61 \\
\hline $\mathrm{T}_{9}$ & 4.30 & - & 1.23 & 1027.77 & - \\
\hline SEm \pm & 0.14 & - & 0.07 & 64.33 & - \\
\hline CDat 5\% & 0.44 & - & 0.23 & 193.01 & - \\
\hline
\end{tabular}

Table.4 Economics of treatments for the management of Alternaria blight of mustard through different spray schedule

\begin{tabular}{|c|c|c|c|c|c|c|c|c|}
\hline Treatmens & $\begin{array}{c}\text { Yield } \\
\text { (kg/ha) }\end{array}$ & $\begin{array}{c}\text { Yield increase } \\
\text { over control } \\
\text { (kg/ha) }\end{array}$ & $\begin{array}{c}\text { Value of } \\
\text { increased } \\
\text { yield (Rs./ha) }\end{array}$ & $\begin{array}{c}\text { Cost of } \\
\text { treatment } \\
\text { application } \\
\text { (Rs/ha) }\end{array}$ & $\begin{array}{l}\text { Gross } \\
\text { income } \\
\text { (Rs/ha) }\end{array}$ & $\begin{array}{c}\text { Net } \\
\text { income } \\
\text { (Rs/ha) }\end{array}$ & $\begin{array}{c}\text { Addition } \\
\text { al } \\
\text { income } \\
\text { (Rs/ha) }\end{array}$ & $\begin{array}{l}\text { Cost } \\
\text { benefi } \\
\text { t ratio }\end{array}$ \\
\hline $\mathrm{T}_{1}$ & 1072.22 & 44.45 & 1444.62 & 753.0 & 34847.15 & 34094.15 & 691.62 & $1: 1.9$ \\
\hline $\mathrm{T}_{2}$ & 1311.11 & 283.34 & 9208.55 & 1506.0 & 42611.07 & 41105.07 & 7702.55 & $1: 6.11$ \\
\hline $\mathrm{T}_{3}$ & 1514.66 & 486.89 & 15823.92 & 2259.0 & 49226.45 & 46967.45 & 13564.92 & $1: 7.18$ \\
\hline $\mathrm{T}_{4}$ & 1763.88 & 736.11 & 23923.57 & 3012.0 & 57326.1 & 54314.1 & 20911.57 & $1: 7.94$ \\
\hline $\mathrm{T}_{5}$ & 1819.44 & 791.67 & 25729.27 & 3765.0 & 59131.8 & 55366.85 & 21964.27 & $1: 6.82$ \\
\hline $\mathrm{T}_{6}$ & 1902.77 & 875.00 & 28437.5 & 4518.0 & 61840.02 & 57201.15 & 23919.5 & $1: 6.29$ \\
\hline $\mathrm{T}_{7}$ & 1922.22 & 894.45 & 29069.62 & 5271.0 & 62472.15 & 58976.0 & 23798.62 & $1: 5.51$ \\
\hline $\mathrm{T}_{8}$ & 2000.0 & 972.23 & 31597.47 & 6024.0 & 65000.0 & - & 25573.47 & $1: 5.24$ \\
\hline $\mathrm{T}_{9}$ & 1027.77 & - & - & - & 33402.52 & - & - & - \\
\hline
\end{tabular}

Note: Mustard Price- Rs 32.5/kg, Labour charge-Rs125/day, Efficiency of sprayer $800 \mathrm{~m}^{2} /$ day, Mancozeb-Rs380/kg.

\section{Infection rate}

Spray of mancozeb was started after first appearance of disease. The progress of disease was recorded at 10 days interval. The perusal of the Table 1 showed that infection rate of the disease was maximum in between 24-12-13 to 3-1-14. After that infection rate gradually decreased in all the treatments. The minimum infection rate on mean basis was recorded in Eight spray of Mancozeb @0.2\% (0.071) followed by Seven spray of Mancozeb @ $0.2 \%$ (0.073), Six spray of Mancozeb @ $0.2 \%$ (0.095), Five spray of Mancozeb @ 0.2 $\%$ (0.126), Four spray of Mancozeb @ $0.2 \%$ (0.135),Three spray of Mancozeb @ $0.2 \%$ (0.152), Two spray of Mancozeb @ $0.2 \%$
(0.168), One spray of Mancozeb @ $0.2 \%$ (0.179) respectively. Maximum infection rate was recorded in unsprayed plot (0.182) (Table $1)$.

\section{Area under Disease Progress Curve (AUDPC)}

All the treatments reduced the AUDPC in comparison to unsprayed plot. The minimum AUDPC was recorded with Eight spray of Mancozeb @ 0.2 \% (190.07) followed by Seven spray of Mancozeb @ $0.2 \%$ (201.0), Six spray of Mancozeb @ $0.2 \%$ (293.50), Five spray of Mancozeb @ $0.2 \%$ (463.50), respectively. Diseases severity increased with decreased number of spraying of fungicide 
mancozeb. Maximum AUDPC was recorded in unsprayed plots (2117.17).

\section{Yield of treatments}

All the treatments also increased the seed yield in comparison to unsprayed plot (Table 4). The seed yield ranged from $1027.77 \mathrm{~kg} / \mathrm{ha}$ to $2000 \mathrm{~kg} / \mathrm{ha}$ in different treatments. The maximum seed yield was recorded in Eight spray of Mancozeb @ $0.2 \%$ (2000 kg/ha) followed by Seven spray of Mancozeb @ 0.2 \% (1922.22 kg/ha), Six spray of Mancozeb @ $0.2 \%$ (1902.77), Five spray of Mancozeb @ $0.2 \% \quad(1819.44 \mathrm{~kg} / \mathrm{ha})$, Four spray of Mancozeb@0.2\%(1763.88kg/ha),Three spray of Mancozeb @0.2\% (1541.66 kg/ha), Two spray of Mancozeb @ $0.2 \%$ (1311.11 $\mathrm{kg} / \mathrm{ha}$ ), One spray of Mancozeb @ $0.2 \%$ $(1072.22 \mathrm{~kg} / \mathrm{ha})$ and minimum seed yield was recorded in unsprayed plot $(1027.77 \mathrm{~kg} / \mathrm{ha})$. No significant difference was noted among treatment unsprayed plot and One spray of Mancozeb @ $0.2 \%$. Similarly treatment five spray of Mancozeb@0.2\%, seven spray of Mancozeb @ $0.2 \%$ and eight spray of Mancozeb @ $0.2 \%$ were at par. However, the two spray of Mancozeb @ $0.2 \%$, three spray of Mancozed @ $0.2 \%$ and four spray of Mancozeb@0.2\% were significantly differ with each other. Yadav et al., (2002) Jagana et al., (2013)

\section{Avoidable yield loss}

The yield loss was avoided from 4.14 to 48.61 per cent in different treatments. The maximum yield loss was avoided with Eight spray of Mancozeb @ $0.2 \%$ (48.61 \%) followed by treatment seven spray of Mancozeb@0.2\%(46.53\%), Six spray of Mancozeb@0.2\% (45.94\%), Five spray of Mancozeb@0.2\% (43.51\%), Four spray of Mancozeb@0.2\% (41.73\%), Three spray of Mancozeb@0.2\% (33.33\%), Two spray of Mancozeb@0.2\% (21.61\%) and One spray of Mancozeb @ $0.2 \%$ (4.14\%), respectively. Prasad and Lallu (2006)

\section{Test weight (1000 seed weight in gm)}

The test weight ranged between 4.30 to $5.50 \mathrm{~g}$. The maximum test weight recorded in eight spray of Mancozeb @ $0.2 \%$ (5.50g) followed by seven and six spray of Mancozeb @ $0.2 \%$ (5.49g), Five spray of Mancozeb @ $0.2 \%$ (5.43gm), Four spray of mancozeb @ $0.2 \%$ (5.30gm), Three spray of Mancozeb @ $0.2 \%$ (5.02gm), Two spray of Mancozeb @ $0.2 \%$ (4.69gm), One spray of Mancozeb @ $0.2 \%$ (4.56gm) and minimum test weight was recorded in unsprayed plot $(4.30 \mathrm{gm})$. The treatment $\mathrm{T}_{9}$ (4.30), $\mathrm{T}_{1}$ (4.46) and $\mathrm{T}_{2}$ (4.69) which was at par with each other and treatment $\mathrm{T}_{3}$ (5.02), $\mathrm{T}_{4}$ (5.30), $\mathrm{T}_{5}$ (5.43), $\mathrm{T}_{6}$ (5.49), $\mathrm{T}_{7}$ (5.50) and $\mathrm{T}_{8}$ (5.50) significantly differ from $\mathrm{T}_{9}, \mathrm{~T}_{1}$ and $\mathrm{T}_{2}$ (Table 3 ). Similar results were recorded by Patni and Kolte (2006). They reported that the maximum test weight (g/1000 seeds) was observed in mancozeb sprayed plants (4.22 g)

\section{Cost benefit ratio}

On the basis of economics the maximum cost benefit ratio $(1: 7.94)$ was obtained with four spray of Mancozeb @ $0.2 \%$ followed by three spray of Mancozeb @ $0.2 \%$ (1:7.18), five spray of Mancozeb @ $0.2 \%$ (1:6.82), six spray of Mancozeb@0.2\% (1:6.29), two spray of Mancozeb @ $0.2 \%$ (1:6.11), seven spray of Mancozeb @ $0.2 \%(1: 5.51)$ and eight spray of Mancozeb @0.2\% (1:5.24), respectively. Minimum cost benefit ratio of 1:1.9 was found with one spray of Mancozeb @ $0.2 \%$ respectively (Table 4). Chattopadhyay and Bhunia (2003)

The use of resistant varieties/ genotypes is considered to be best method of disease control. Therefore, the studies were carried out to find out the sources of resistance 
against the Alternaria blight. A total of fifteen genotypes/varieties of Indian mustard were evaluated for their reaction against the disease under field condition.

\section{References}

Barma, B., and Bhagawati, R. 1995. Assessment of yield loss due to Alternaria brassicae in mustard. Plant Health, 1: 80-82.

Berkeley, M.J., 1836. Fungi In: Smith JEand Hookar JW (end). The English Flora. Vol. V, Part II. Longman, London, pp. 339-340.

Bond, T.E.T., 1947. Notes of ceylon fungi and plant disease. Ceylon J.Sci. Sec., A7:171-193.

Borg, A., 1952. Some plant disease and pests in West Gothland. Rev. Appl. Mycol., 31:103-152

Butler, E. J., 1918. Fungi and disease in plant. Jayyed Press, Ballimaran, Delhi. Pp130133

Chattopadhyay, A.K., and C.K. Bhunia. 2003. Management of Alternaria leaf blight of rapeseed mustard by chemicals. $J$. Mycopathol. Res., 41(2): 181-183.

Chattopadhyay, C., P.D. Meena and S. Kumar, 2002. Management of Sclerotinia rot of Indan mustard using ecofriendly strategies. J. Mycol. Pl. Pathol., 32, 194-200.

Fisher, R.A., and Yates. F. 1957. Statistical Tables for Biological, Agricultural and Medicinal Research (5th Edition), Hafner, New York.

Girish, G., Gowda, M.B., Saifulla, M., Mahesh, M. and Satheesh. 2007. Management of White Rust and A. blight of mustard using fungicides. Environment and Ecology, 3: 830-833.

Girish, G., M. Gowda, B. Saifulla, M. Mahesh and M. Satheesh. 2007. Management of white rust and Alternaria leaf blight of mustard using fungicides. Environ. Eco,
25(3A): 830-833.

Jagana, M., S. Zacharia, A.A. Lal and Basayya 2013. Management of Alternaria blight in mustard. Ann. Pl. Protec. Sci., 21(2): 441- 442.

Kolte, S.J., 1985. Disease of Annual Edible Oilseed Crops. Volume II RapeseedMustard and Sesame Disease. C.R.C. Press. Inc. Boca. Raton, Florida pp. 135.

Kolte, S.J., 1987. Assessment of yield losses due to Alternaria blight in rapeseed and mustard. Indian Phytopath, 40 (2): 209211.

Kolte, S.J., 2002. Diseases and their management in oilseed crops, new paradigm in oilseeds and oil: research and development needs (Raimangla, Harvir Singh, D.M. Hegde Ed.) Indian Society of Oilseeds Research, 244-252.

Kolte, S.J., and Tiwari, A.N. 1978. Efficacy of certain chemicals for the control of Alternaria blight of yellow sarson. Indian Phytopathol, 31(1):81-84

Kumar, A., and Chauhan, J. S. 2005. Strategies and future thrust areas of rapeseed mustard research in India. Ind. J. Agric. Sci., 75:621-635

Kumar, D., Maurya, N., Bharti, Y. K., Kumar, A., Kumar, K., Srivastava, K., Chand, G., Kushwaha, C., Singh, S. K., Mishra, R. K. and Kumar, A. 2014. Alternaria blight of oilseed Brassicas: A comprehensive review. African Journal of Microbiology, 8(30):2816-2829.

Meena, P.D., Meena, R.L., Chattopadhyay, C and Kumar, Arvind. 2004. Identification of critical stage for disease development and biocontrol of Alternaria blight of Indian mustard (Brassica juncea). $J$ Phytopath, 152: 204-209.

Mondal, K.K., Bhattacharya, R.C., Koundal, K.R. and Chatterji, S.C. 2007. Transgenic Indian mustard (Brassica juncea) expressing tomato glucanase leads to arrested growth of Alternaria 
brassicae. Plant Cell Rep., 26:247-252

Patni, C.S., and S.J. Kolte. 2006. Effect of some botanicals in management of Alternaria blight of rapeseed mustard. Ann. Pl. Protec. Sci., 14: 151-156.

Rajendra, P., and Lallu. 2006. Management of A. blight of mustard with combination of chemicals and botanicals. Annals of Plant Protection Science. 14 (2): 400403.

Saharan, G.S., 1992. In "Advances in Oilseed Research". Vol. I (Eds. Kumar, D. and Rai, M.). Scientific Publishers, Jodhpur, pp. 152-181.
Yadav, M.S., Dhillon, S.S. and Dhiman, J.S. 2002. Effect of date of sowing, varieties and chemical treatments on the development of Alternaria blight and White rust of mustard. Journal of Research, Punjab Agricultural University, 39 (4): 528- 532.

Yadav, M.S., S.S. Dhillon and J.S. Dhiman. 2002. Effect of date of sowing, varieties and chemical treatments on the development of Alternaria blight and white rust of mustard. J. Res., 39(4): 528- 532.

\section{How to cite this article:}

Manoj Kumar Pandey, Narender Kumar, Hemant Kumar Singh and Surender Kumar. 2018. Effect of Mancozeb on Disease Severity, Infection Rate and Seed Weight of Mustard [Brassica juncea (L.) Czen \& Coss.] Caused by Alternaria spp. Int.J.Curr.Microbiol.App.Sci. 7(02): 3689-3699. doi: https://doi.org/10.20546/ijcmas.2018.702.438 